\title{
Impact of Embossing on Liquid Absorption of Toilet Tissue Papers
}

\author{
Joana Costa Vieira, ${ }^{\mathrm{a}, *}$ António de Oliveira Mendes, ${ }^{\mathrm{a}}$ Ana Margarida Carta, ${ }^{\mathrm{b}}$ \\ Enrico Galli, ${ }^{\mathrm{c}}$ Paulo Torrão Fiadeiro, ${ }^{\mathrm{a}}$ and Ana Paula Costa ${ }^{\mathrm{a}}$

\begin{abstract}
Absorption capacity is a key feature of toilet tissue papers. Several parameters can affect their final absorption capacities, such as pulp composition, stock preparation, number of sheets, additives, bulk, grammage, and converting process parameters, such as the embossing operation. In this work, the absorption capacities of four different 2-ply industrial toilet tissue papers, as well as the respective base papers from the mother-reel was compared using the immersion method according to ISO 12625-8 (2010). Previously, these samples were characterized in terms of morphology, grammage, thickness, and bulk. It was concluded that the embossing operation noticeably increased the thickness and bulk of toilet tissue paper. Furthermore, it was also verified that among the various toilet tissue paper samples there was not a noticeable variation in the time of water absorption because the samples revealed similar morphology and porosity. However, it was found that the bulk increased more than $150 \%$, resulting in an increase of water absorption capacity over
\end{abstract} \\ $60 \%$.
}

Keywords: Tissue paper; Embossing; Paper morphology; Liquid absorption capacity; Porosity

Contact information: a: Universidade da Beira Interior, Fiber Materials and Environmental Technologies (FibEnTech-UBI), Rua Marquês de Ávila e Bolama, 6201-001, Covilhã, Portugal; b: RAIZ - Instituto de Investigação da Floresta e Papel, Quinta de S. Francisco, Apartado 15, 3801-501, Eixo, Portugal; c: The Navigator Company, R. dos Bombeiros da Celulose, 3800-536, Cacia, Portugal;

*Corresponding author: joana.costa.vieira@ubi.pt

\section{INTRODUCTION}

Tissue papers, namely toilet paper, kitchen towels, and napkins, have distinctive characteristics from printing and writing papers. Tissue paper is characterized by its physical and mechanical properties, namely softness, low grammage, bulk, high flexibility, and liquid absorption capacity. In contrast to printing and writing papers, in which the finishing process, the calendering operation, is the most important step, in tissue paper the key processing operations include creping and embossing, which are lesser studied.

Embossing is the mechanical process of sculpturing tissue paper during converting. Moreover, providing the physical connection between the different sheets of paper, it embosses (by applying a localized pressure) a decoration pattern that contributes to the bulk increase, compressibility, liquid absorption capacity, and softness (Spina and Cavalcante 2018). Currently, various types of embossing technologies are used. In general only pressure is applied, but the usage and control of temperature and humidity are emerging, resulting in various products (DeMaio and Patterson 2008; Biagiotti 2017).

Figure 1 shows the steps of the converting process, starting from the unwinding of the paper mother-reel produced in the tissue paper machine, passing through the embossing process, until the final product is palletized (Kimari 2000). 


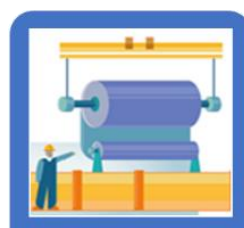

Unwinder

(one or more than

one sheet in the

same mother-reel)

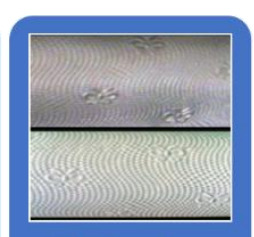

Embossing

(engraving in high

and low relief /

and low relief /
addition or not

colored pigment)

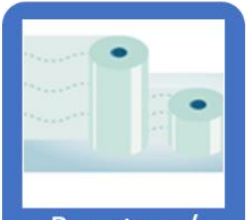

Puncture/

Rewinder

(services marked

with perforation /

paper rewind in

LOGs with final roll diameter)

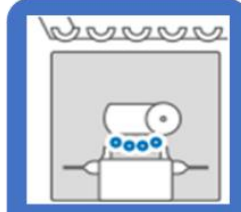

Cut

(cutting LOGs into

final dimension

rolls)

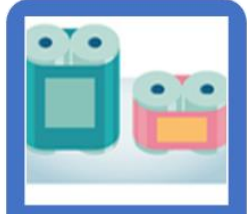

Packing

(packaging rollers

according customer

specifications)

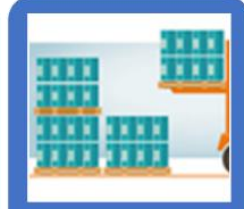

Palletizing

(pallets assembling

for space

optimization)

Fig 1. Steps of tissue paper converting process to the finished product

Embossing the top layer of tissue papers (with one or more plies), is known as deco (decorative) embossing. In contrast, embossing the bottom layer is known as micro embossing. This is usually the case of toilet paper products. The resulting product with more sheets/plies has properties that cannot be achieved by a single paper layer finished product (Digby 2012).

Although the embossing process improves some properties of tissue papers, it can impair other properties. Thus, certain properties, such as tensile strength and thickness, may be reduced. Liquid absorption is a key property for most tissue paper products and its main purpose is to improve cleaning and liquid absorption. It is generally better defined as absorption capacity, and absorption rate or absorption time (Hollmark 1983; Tutuş et al. 2016). Absorption capacity reflects the maximum amount of water the paper can absorb until its saturation and is expressed in gram of water per gram of fiber, while the absorption rate measures how quickly tissue products absorb water (Hollmark 1983; Kullander 2012). In the tissue world, both water absorption time and water absorption capacity are important parameters used to compare different tissue papers (Tutuş et al. 2016).

Beyond embossing, liquid absorption capacity and absorption rate/time can also be controlled by fiber type, fines content, refining, fiber network structure, pressing, creping, number of sheets, additives, bulk, grammage, and porosity (Kullander 2012; De Assis et al. 2018).

The porosity of base and final tissue papers is an important parameter for liquid absorption. Absorption measurements indicate the ability of a paper to hold a liquid. The pores in the paper/fibrous network influence water passages by capillarity action in all directions. In addition, the amount/volume of pores influences the amount of water the paper is able to accommodate. To enhance water absorption, the porosity should not be too high, because this would lead to fewer contact points with the liquid and thus less absorption. In contrast, if porosity is too low, this increases the resistance to capillary transport of liquids and thus decreases absorption. The optimal porosity must enable the liquid to be absorbed by cohesive forces but, at the same time, it must hinder its removing due to gravity without impairing the penetration rate. Porosity is influenced by pore size, which in turn depends on fiber size, degree of collapse resistance, and interfiber bonding (Milanez and Rost 2005). Hydroxyl groups on cellulose surface form hydrogen bonds with water, which directly affects water absorption (Bracken 2014).

Bulk also influences absorption. Papers with higher bulk values, i.e., less dense with a more porous structure, will reveal higher absorption values, because paper will exhibit more sites for water accommodation. In addition to these aspects, factors such as surface energy of the phases involved (water, paper, and water vapor), contact angle, 
roughness, topography, and position of the paper (pro or against gravity), influence the paper absorption (Milanez and Rost 2005).

Absorption properties are also strongly dependent on the surface chemistry of the fibers. In this context, to optimize absorption of tissue paper, the main elements that directly influence this characteristic should be well controlled and balanced, such as the type of pulp used, white water chemistry, and added additives. In summary, paper absorption is influenced by the manufacturing process, the composition of the raw materials, and the bulk of the paper (Milanez and Rost 2005; De Assis et al. 2018).

Specifically, the ability to absorb water more quickly is a key attribute of tissue paper. Gigac and Fiserová (2008) found that absorption decreased, when comparing different pulps with increased refining. Pulps that were less sensitive to refining maintained the highest levels of absorption. Although with low refining levels, kraft pulp showed a higher absorption.

Absorption also depends on the pulp's chemical composition. Pulps containing a high lignin content indicated a low absorption of liquids (De Assis et al. 2018). Thus, mechanical pulps (high lignin content) absorb approximately $1.0 \mathrm{~g}$ water/g fiber. Tissue products based on recycled fibers typically absorb approximately $4.0 \mathrm{~g}$ water/g fiber, while bleached kraft pulps (residual lignin contents) absorb between 5.0 and $10.0 \mathrm{~g}$ water/g fiber. Premium tissue products can achieve absorption capacities of up to $18.0 \mathrm{~g}$ water/g fiber (Kullander 2012; Hubbe et al. 2013; De Assis et al. 2018).

This work presents the results of a study regarding the impact of embossing on the absorption capacity of industrial toilet papers using the immersion method according to ISO 12625-8 (2010). A set of six base and the respective four toilet paper samples were directly collected in the converting line. The base papers were produced in the same tissue paper machine using a mixture of hardwood and softwood bleached kraft pulps and were compared in terms of water absorption before and after the embossing operation carried out in the same embossing conditions. The embossing pattern designs used in our samples are those available on the industrial converting line through steel engraving embossing rolls against rubber rolls.

\section{EXPERIMENTAL}

\section{Materials}

In this study, four different 2-ply toilet papers as well as the respective base paper mother-reels were used, supplied by a Portuguese tissue paper manufacturer. These industrial base tissue papers have been produced with a grammage range 16 to $19 \mathrm{~g} / \mathrm{m}^{2}$, being the mother-reels and toilet papers composed by 2 sheets. Papers were organized according to Table 1. The designation of A1, B1, and $\mathrm{C} 1$ correspond to the base paper mother-reels on the unwinder-1 of the converting machine (top sheet of the final toilet papers $\mathrm{A}, \mathrm{B}, \mathrm{C}$, and $\mathrm{D}$, respectively), and $\mathrm{A} 2, \mathrm{~B} 2$, and $\mathrm{C} 2$ correspond to the base paper mother-reels on the unwinder- 2 of the same machine (bottom sheet of the final toilet papers $\mathrm{A}, \mathrm{B}, \mathrm{C}$, and D, respectively). All essays on the mother-reels were completed with two sheets, one from unwinder-1 and the other from unwinder-2. Toilet papers A and B were produced from different mother-reels, and different deco/micro embossing patterns. The others toilet papers $\mathrm{C}$ and $\mathrm{D}$ were produced from the same mother-reels, but with different deco and the same micro embossing patterns. Table 1 shows the images of both surfaces of each paper, on which the differences between them in terms of embossing (deco and 
Then, the grammage, defined as the mass per unit paper area, was determined and expressed in $\mathrm{g} / \mathrm{m}^{2}$. It was determined by weighing the tissue paper sample to a known area in accordance with ISO 12625-6 (2005) and using a Mettler Toledo PB303 Delta range analytical balance (Mettler Toledo, Columbus, OH, USA). The thickness was also determined using a FRANK-PTI ${ }^{\circledR}$ Micrometer (FRANK-PTI GMBH, Birkenau, Germany), where a sheet of tissue paper or a stack of sheets of tissue paper was compressed at a given pressure between two parallel plates according to ISO 12625-3 (2014). Finally, the bulk, which is the inverse of density, was determined by using the grammage and thickness according to ISO 12625-3 (2014).

Then, the porosity was determined for all the toilet paper and base mother-reels samples using a Micromeritics AccuPyc II 1340 helium pycnometer (Micromeritics, Norcross, GA, USA). Apparent porosity (theoretical) was calculated using Eq. 1,

$$
P(\%)=100 \times\left(1-\frac{\rho_{\text {sample }}}{\rho_{\text {cellulose }}}\right)
$$

where $\rho_{\text {sample }}$ is the sample density $\left(\mathrm{g} / \mathrm{cm}^{3}\right)$ and $\rho_{\text {cellulose }}$ is the cellulose density (which is assumed to be $\left.1.6 \mathrm{~g} / \mathrm{cm}^{3}\right)$ (Costa et al. 2016).

Finally, the absorption capacity and the absorption time were measured by the immersion method according to ISO 12625-8 (2010) using a FRANK-TPI® tissue absorption tester (FRANK-PTI GMBH, Birkenau, Germany). The industrial toilet paper samples were cut according to the above standard. The mother-reel paper samples were prepared and cut following the toilet paper dimensions, in machine direction, according the same standard. The samples have a width of $76 \pm 1 \mathrm{~mm}$ and a length of the respective toilet paper service in sufficient number to achieve a mass of $5.0 \pm 0.2 \mathrm{~g}$.

In terms of image acquisition, a customized optical system (Prototype, University of Beira Interior, Covilhã, Portugal) previously used in research for other purposes (Mendes et al. 2013, 2014, and 2015) was conveniently configured for inspection of the papers' surfaces using specific conditions of illumination and magnification. The images were captured with fields of view of approximately $77 \times 77 \mathrm{~mm}^{2}$ and $10 \times 10 \mathrm{~mm}^{2}$, a resolution of $1024 \times 1024$ pixels, and a bit depth of 10 bits (1024 gray levels).

\section{RESULTS AND DISCUSSION}

The fibers morphological characterization of the industrial tissue paper samples used are presented in Tables 2, 3, and 4. It can be verified that both the mother-reels and the finished paper product were comparable, with no relevant variation of their values. Knowing that the samples were produced on the same industrial tissue paper machine under similar conditions, one can say that their networks of fibrous structure are analogous and consequently the porosity will not be an influencing factor in these tests of absorption capacity and water absorption time.

From the results presented in the following tables, one can state that the fiber composition of all the samples was similar, and it did not have any influence on the study of the embossing impact on the liquid absorption. 
Table 2. Mean Values and Standard Deviations of the Morphological Results Obtained for the Mother-reels A1 and A2, and the Toilet Paper A

\begin{tabular}{|c|c|c|c|c|c|c|}
\hline \multirow{2}{*}{ Morphology } & \multicolumn{2}{|c|}{ Mother-reel A1 } & \multicolumn{2}{c|}{ Mother-reel A2 } & \multicolumn{2}{c|}{ Paper A } \\
\cline { 2 - 6 } & $\bar{x}$ & $\sigma$ & $\bar{x}$ & $\sigma$ & $\bar{x}$ & $\sigma$ \\
\hline Fibers (million / g) & 16.7 & \pm 0.2 & 18.6 & \pm 0.5 & 17.1 & \pm 0.2 \\
\hline $\begin{array}{c}\text { Length Weighted in } \\
\text { Length (mm) }\end{array}$ & 0.860 & \pm 0.006 & 0.828 & \pm 0.007 & 0.835 & \pm 0.006 \\
\hline Width $(\mu \mathrm{m})$ & 20.1 & \pm 0.1 & 20.0 & \pm 0.2 & 19.9 & \pm 0.2 \\
\hline Coarseness $(\mathrm{mg} / 100 \mathrm{~m})$ & 8.80 & \pm 0.00 & 8.10 & \pm 0.00 & 8.70 & \pm 0.00 \\
\hline Kink Fibers (\%) & 47.9 & \pm 0.6 & 47.9 & \pm 0.1 & 46.5 & \pm 0.4 \\
\hline Curl (\%) & 10.2 & \pm 0.0 & 10.4 & \pm 0.0 & 10.2 & \pm 0.1 \\
\hline Broken Ends (\%) & 24.8 & \pm 0.2 & 25.4 & \pm 1.8 & 24.7 & \pm 0.2 \\
\hline Fines (\% Area) & 16.1 & \pm 0.7 & 16.1 & \pm 1.8 & 14.1 & \pm 0.4 \\
\hline
\end{tabular}

Table 3. Mean Values and Standard Deviations of the Morphological Results Obtained for the Mother-reels B1 and B2, and the Toilet Paper B

\begin{tabular}{|c|c|c|c|c|c|c|}
\hline \multirow{2}{*}{ Morphology } & \multicolumn{2}{|c|}{ Mother-reel B1 } & \multicolumn{2}{|c|}{ Mother-reel B2 } & \multicolumn{2}{c|}{ Paper B } \\
\cline { 2 - 6 } & $\bar{x}$ & $\sigma$ & $\bar{x}$ & $\sigma$ & $\bar{x}$ & $\sigma$ \\
\hline Fibers (million / g) & 18.0 & \pm 1.1 & 14.7 & \pm 0.2 & 16.1 & \pm 0.5 \\
\hline $\begin{array}{c}\text { Length Weighted in } \\
\text { Length (mm) }\end{array}$ & 0.850 & \pm 0.007 & 0.930 & \pm 0.004 & 0.889 & \pm 0.003 \\
\hline Width ( $\mu \mathrm{m})$ & 19.5 & \pm 0.1 & 20.8 & \pm 0.2 & 20.0 & \pm 0.2 \\
\hline Coarseness (mg/100 m) & 8.04 & \pm 0.00 & 9.47 & \pm 0.00 & 8.82 & \pm 0.00 \\
\hline Kink Fibers (\%) & 40.1 & \pm 0.2 & 43.7 & \pm 0.2 & 42.4 & \pm 0.3 \\
\hline Curl (\%) & 9.2 & \pm 0.0 & 10.0 & \pm 0.0 & 9.6 & \pm 0.1 \\
\hline Broken Ends (\%) & 23.2 & \pm 0.3 & 26.8 & \pm 0.3 & 24.2 & \pm 0.3 \\
\hline Fines (\% Area) & 14.1 & \pm 0.1 & 14.3 & \pm 0.3 & 13.0 & \pm 0.8 \\
\hline
\end{tabular}

Table 4. Mean Values and Standard Deviations of the Morphological Results Obtained for the Mother-reels C1 and C2, and the Toilet Papers C and D

\begin{tabular}{|c|c|c|c|c|c|c|c|c|}
\hline \multirow{2}{*}{ Morphology } & \multicolumn{2}{|c|}{ Mother-reel C1 } & \multicolumn{2}{|c|}{ Mother-reel C2 } & \multicolumn{2}{c|}{ Paper C } & \multicolumn{2}{c|}{ Paper D } \\
\cline { 2 - 8 } & $\bar{x}$ & $\sigma$ & $\bar{x}$ & $\sigma$ & $\bar{x}$ & $\sigma$ & $\bar{x}$ & $\sigma$ \\
\hline Fibers (million / g) & 16.8 & \pm 0.4 & 17.4 & \pm 0.2 & 16.3 & \pm 0.6 & 16.3 & \pm 0.2 \\
\hline $\begin{array}{c}\text { Length Weighted in } \\
\text { Length (mm) }\end{array}$ & 0.862 & \pm 0.010 & 0.859 & \pm 0.002 & 0.862 & \pm 0.007 & 0.870 & \pm 0.009 \\
\hline Width ( $\mu \mathrm{m})$ & 20.0 & \pm 0.1 & 20.3 & \pm 0.3 & 19.8 & \pm 0.1 & 19.9 & \pm 0.1 \\
\hline $\begin{array}{c}\text { Coarseness } \\
\text { (mg/100 m) }\end{array}$ & 8.73 & \pm 0.26 & 8.48 & \pm 0.12 & 9.00 & \pm 0.34 & 8.94 & \pm 0.14 \\
\hline Kink Fibers (\%) & 130.8 & \pm 0.3 & 130.7 & \pm 0.2 & 130.6 & \pm 0.3 & 130.4 & \pm 0.3 \\
\hline Curl (\%) & 10.1 & \pm 0.0 & 10.4 & \pm 0.0 & 10.0 & \pm 0.0 & 10.0 & \pm 0.1 \\
\hline Broken Ends (\%) & 25.3 & \pm 0.1 & 26.3 & \pm 1.9 & 24.6 & \pm 0.3 & 24.6 & \pm 0.4 \\
\hline Fines (\% Area) & 14.7 & \pm 0.1 & 16.1 & \pm 1.9 & 13.9 & \pm 0.6 & 13.9 & \pm 0.1 \\
\hline
\end{tabular}


Table 5 shows the grammage, thickness, and bulk results for the samples under study, determined according to the above-referred standards.

Table 5. Results Obtained on the Determination of Grammage, Thickness, and Bulk of Mother-reels $(A 1+A 2),(B 1+B 2),(C 1+C 2)$, and the Toilet Papers $A, B$, C, and D

\begin{tabular}{|c|c|c|c|c|c|c|c|}
\hline & $\begin{array}{c}\text { Mother- } \\
\text { reels } \\
(\mathbf{A 1}+\mathbf{A 2})\end{array}$ & $\begin{array}{c}\text { Paper } \\
\text { A }\end{array}$ & $\begin{array}{c}\text { Mother- } \\
\text { reels } \\
\text { (B1+ B2) }\end{array}$ & $\begin{array}{c}\text { Paper } \\
\text { B }\end{array}$ & $\begin{array}{c}\text { Mother- } \\
\text { reels } \\
(\mathbf{C 1}+\mathbf{C 2})\end{array}$ & $\begin{array}{c}\text { Paper } \\
\text { C }\end{array}$ & $\begin{array}{c}\text { Paper } \\
\text { D }\end{array}$ \\
\hline Grammage $\left(\mathrm{g} / \mathrm{m}^{2}\right)$ & 33.2 & 32.4 & 37.9 & 37.3 & 32.4 & 31.4 & 32.1 \\
\hline Thickness $(\mu \mathrm{m})$ & 241 & 619 & 259 & 477 & 243 & 611 & 612 \\
\hline Bulk $\left(\mathrm{cm}^{3} / \mathrm{g}\right)$ & 7.3 & 19.1 & 6.8 & 12.8 & 7.5 & 19.5 & 19.1 \\
\hline
\end{tabular}

Looking at the results in Table 5 it can be seen that the grammage has values that correspond to a composition of two sheets, hence showing values in the range of 31.4 to $37.9 \mathrm{~g} / \mathrm{m}^{2}$. The differences of grammage evidenced for the analyzed samples are related with the individual grammage of each sheet (16 to $\left.19 \mathrm{~g} / \mathrm{m}^{2}\right)$ but yet, within the allowed industrial tolerance. Comparing the results before and after the embossing operation, the thickness and bulk values increased with this process.

Table 6 shows the apparent and the measured porosity for all samples under study.

Table 6. Results of the Apparent and the Measured Porosities of Mother-reels $(A 1+A 2),(B 1+B 2),(C 1+C 2)$, and the Toilet Papers A, B, C, and D

\begin{tabular}{|c|c|c|}
\hline & Apparent Porosity (\%) & Porosity (\%) \\
\hline Mother-reel (A1 + A2) & 91.0 & 91.0 \\
\hline Paper A & 96.6 & 96.2 \\
\hline Mother-reel (B1 + B2) & 90.5 & 89.8 \\
\hline Paper B & 94.9 & 92.4 \\
\hline Mother-reel (C1 + C2) & 91.3 & 90.9 \\
\hline Paper C & 96.7 & 95.2 \\
\hline Paper D & 96.6 & 94.9 \\
\hline
\end{tabular}

Table 6 shows the results and comparison of the apparent porosities of the toilet papers and the respective mother-reels. The apparent porosity and the measured porosity were similar for all samples; meanwhile the toilet papers revealed a higher porosity in comparison with the corresponding mother-reels, due to the embossing process impact. The porosity differences between mother-reels and papers is due to the increase of the air gap volume between the 2 sheets during the embossing operation, given more bulk to the papers, which will allow a greater liquid retention.

Finally, Table 7 summarizes the mean values and standard deviations for the achieved results on water absorption time and the absorption capacity tests of all samples under study, according to the above-referred standard.

In Fig. 2, it can be seen that the water absorption time, determined for the various papers (mother-reels and final tissue paper products), was close in value, which also justified an equivalent fibrous structural network and a similar porosity. In such way, the embossing operation itself does not influence the absorption time results. 
Table 7. Mean Values and Standard Deviations of the Results from Water Absorption Time and Absorption Capacity Tests of Mother-reels (A1 + A2), (B1 + B2), $(C 1+C 2)$, and the Toilet Papers A, B, C, and D

\begin{tabular}{|c|c|c|c|c|}
\hline & \multicolumn{2}{|c|}{ Water Absorption Time (s) } & \multicolumn{2}{c|}{ Absorption Capacity (g/g) } \\
\hline & $\bar{X}$ & $\sigma$ & $\bar{X}$ & $\sigma$ \\
\hline Mother-reels (A1 + A2) & 3.82 & \pm 0.23 & 8.71 & \pm 0.37 \\
\hline Paper A & 3.80 & \pm 0.30 & 13.94 & \pm 0.27 \\
\hline Mother-reels (B1 + B2) & 4.59 & \pm 0.38 & 7.97 & \pm 0.24 \\
\hline Paper B & 4.63 & \pm 1.11 & 9.38 & \pm 0.26 \\
\hline Mother-reels (C1 + C2) & 3.92 & \pm 0.46 & 8.21 & \pm 0.21 \\
\hline Paper C & 4.73 & \pm 0.52 & 13.72 & \pm 0.30 \\
\hline Paper D & 4.24 & \pm 0.40 & 14.10 & \pm 0.18 \\
\hline
\end{tabular}

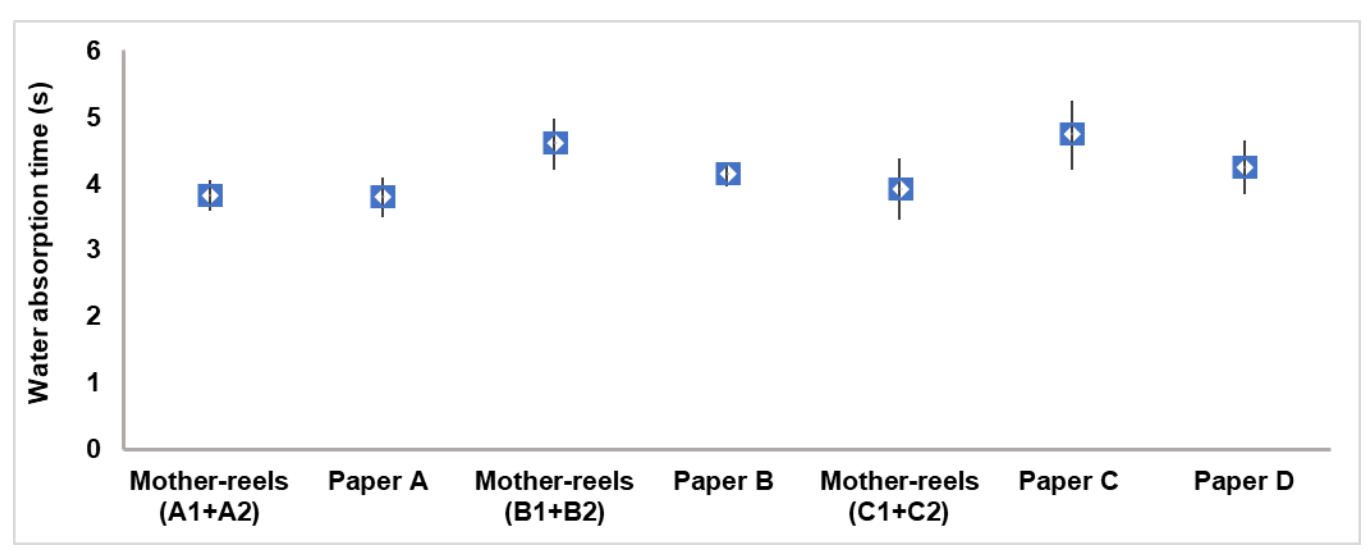

Fig. 2. Water absorption time of the tested samples

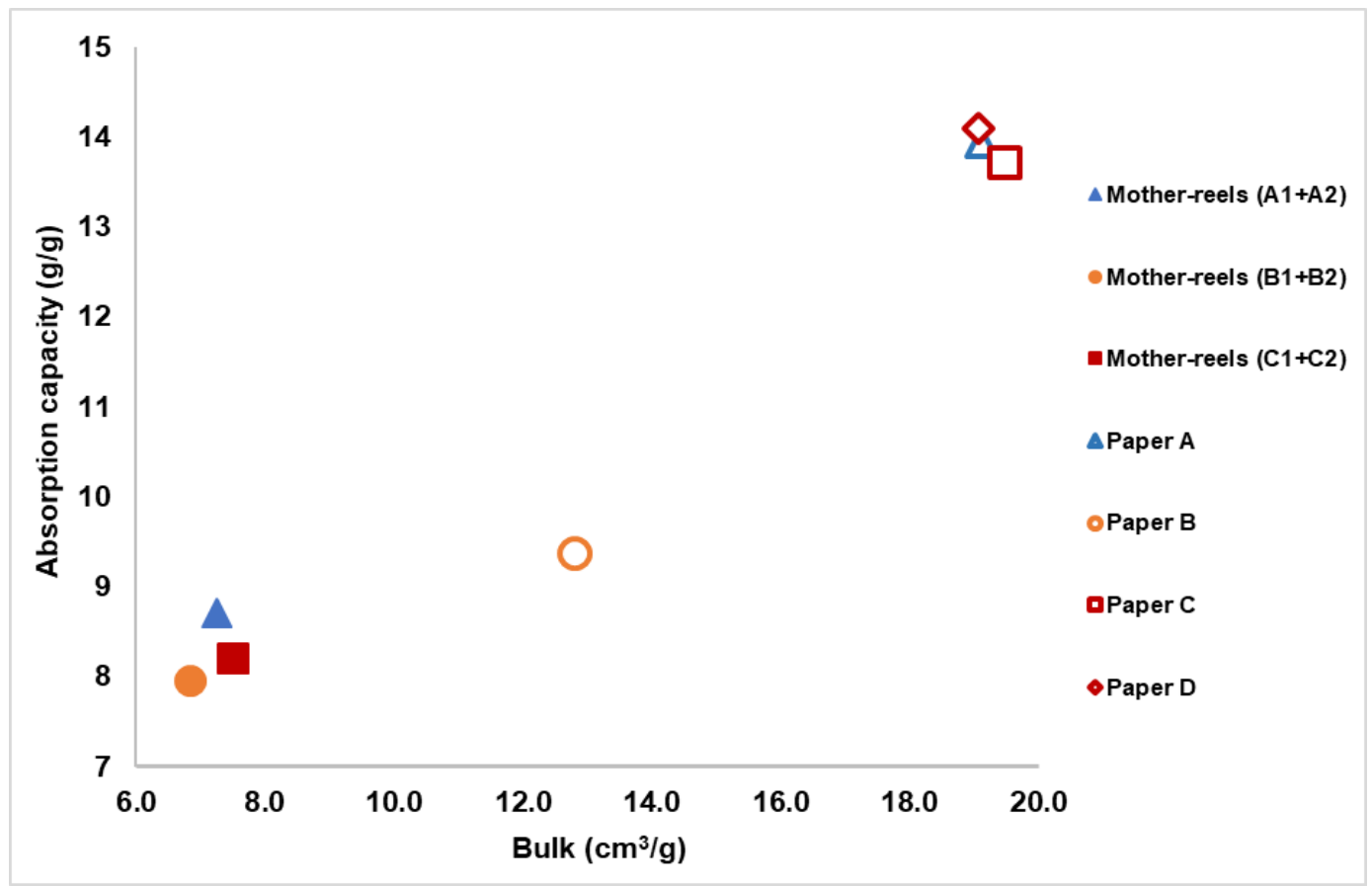

Fig. 3. Variation of water absorption capacity with bulk of the tested samples 
Based on Fig. 3 (water absorption capacity $v s$. bulk), with the increase of the bulk there was an increase in water absorption capacity. Due to the embossing processes, bulk increases of $163 \%, 87 \%, 159 \%$, and $154 \%$ for the toilet papers A, B, C, and D, respectively, were observed. This led to an increase in water absorption capacity of $60 \%, 18 \%, 67 \%$, and $72 \%$ for the same toilet papers. Thus, a greater bulk and porosity increase led to a greater water absorption capacity. This bulk increment results from the thickness gain induced by the embossing process, and it will be more pronounced as deeper the embossing pattern is engraved.

\section{CONCLUSIONS}

1. In this study, a set of tissue paper samples (base mother-reels and the corresponding finished toilet papers), exhibited a similar morphological characterization. Because the base papers were produced on the same industrial paper machine under the same conditions, the fibrous networks were equivalent. This was also demonstrated by the apparent and the measured porosity results of the base paper mother-reels (approximately $91 \%$ in all cases). In contrast, the apparent and the measured porosity results of the toilet papers increased relative to the corresponding mother-reels (between $92 \%$ and 97\%). This was attributed to the results from the embossing process because the fibrous networks were similar.

2. It was concluded that the embossing operation substantially increased the thickness and the bulk of the toilet papers. The differences in percentage of increase were dependent on the embossing pattern and the operation conditions of the converting machine.

3. Moreover, the embossing operation had no relevant implication on the time of water absorption, when comparing the paper mother-reels with the toilet papers, because they presented similar values with small variations. Additionally, there was not a relevant variation in the time of water absorption because the tissue paper samples were morphologically similar. However, the embossing operation had a major impact on water absorption capacity, promoting water absorption, due to the bulk increase.

4. With the embossing operation, bulk increased more than $150 \%$, resulting in an increase of water absorption capacity over $60 \%$.

\section{ACKNOWLEDGMENTS}

This work was carried out under the Innovative Products and Technologies project from Eucalyptus, Project No. 21874, funded by Portugal 2020 through European Regional Development Fund (ERDF) in the frame of COMPETE 2020 No. 246/AXIS II/2017.

The authors are also very grateful for the support given by Fiber Materials and Environmental Technologies (FibEnTech-UBI) on the extent of the project reference UIDB/00195/2020. 


\section{REFERENCES CITED}

Biagiotti, M. (2017). “Tissue embossing developments - the tissue story," Tissue Story, (https://www.tissuestory.com/2017/11/21/tissue-embossing-developments/), Accessed 8 Jan 2019.

Bracken, L. (2014). Potential for Utilization of Novel Modified Pulps in Tissue Paper Grades, Master of Chemical Engineering Dissertation, Miami University, Oxford, $\mathrm{OH}, \mathrm{USA}$.

Costa, V. L. D., Costa, A. P., Amaral, M. E., Oliveira, C., Gama, M., Dourado, F., and Simões, R. M. (2016). "Effect of hot calendering on physical properties and water vapor transfer resistance of bacterial cellulose films," Journal of Materials Science 51(21), 9562-9572. DOI: 10.1007/s10853-016-0112-4

De Assis, T., Reisinger, L., Pal, L., Pawlak, J., Jameel, H., and Gonzalez, R. (2018). "Understand the effect of machine technology and cellulosic fibers on tissue properties - A review," BioResources 13(2), 4593-4629. DOI: 10.15376/biores.13.2.

DeMaio, A., and Patterson, T. (2008). "Similarities in bonding influence between prefailure tensile creep and stress-strain behavior of paper," Mechanics of Materials 40(3), 133-149. DOI: 10.1016/j.mechmat.2007.06.007

Digby, P. (2012). "pd-Tissues - Trees to paper," (http://pd-tissues.co.uk/trees-topaper.aspx), Accessed 13 Feb 2019.

Gigac, J., and Fišerová, M. (2008). "Influence of pulp refining on tissue paper properties,” TAPPI Journal 7(8), 27-32.

Hollmark, H. (1983). Handbook of Physical and Mechanical Testing of Paper and Paperboard: Chapter 20 - Absorbency of Tissue and Towelling, (R. E. Mark, ed.), Dekker, New York.

Hubbe, M. A., Ayoub, A., Daystar, J. S., Venditti, R. A., and Pawlak, J. J. (2013). "Enhanced absorbent products incorporating cellulose and its derivatives: A review," BioResources 8(4), 6556-6629-6629. DOI: 10.15376/biores.8.4.6556-6629

ISO 12625-3 (2014). "Tissue paper and tissue products - Part 3: Determination of thickness, bulking thickness and apparent bulk density and bulk," International Organization for Standardization, Geneva, Switzerland.

ISO 12625-6 (2005). "Tissue paper and tissue products - Part 6: Determination of grammage," (2005). International Organization for Standardization, Geneva, Switzerland.

ISO 12625-8 (2010). "Tissue paper and tissue products - Part 8: Water-absorption time and water-absorption capacity, Basket-immersion test method," International Organization for Standardization, Geneva, Switzerland.

Kimari, O. (2000). Papermaking Science and Technology: 18 - Paper and Board Grades by Hannu Paulapuro, (J. Gullichsen, H. Paulapuro, Suomen Paperi-Insinöörien Yhdistys, and Technical Association of the Pulp and Paper Industry, eds.), Fapet Oy, Helsinki.

Kullander, J. (2012). Evaluation of Furnishes for Tissue Manufacturing, Ph.D. Thesis, Karlstads Universitet, Karlstad, Sweden.

Mendes, A. O., Fiadeiro, P. T., Costa, A. P., Amaral, M. E., and Belgacem, M. N. (2013). "Retro-diffusion and transmission of laser radiation to characterize the paper fiber distribution and mass density," in: Proceedings of the 8th Iberoamerican Optics Meeting and 11th Latin American Meeting on Optics, Lasers, and Applications, Volume 8785, Porto, Portugal, Paper Number 8785AY. DOI: 10.1117/12.2022367 
Mendes, A. O., Fiadeiro, P. T., Costa, A. P., Amaral, M. E., and Belgacem, M. N. (2014). "Study of repeatability of an optical laser system for characterization of the paper fiber distribution and mass density," in: Proceedings of the Second International Conference on Applications of Optics and Photonics, Volume 9286, Aveiro, Portugal, Paper Number 92862Y. DOI: 10.1117/12.2062697

Mendes, A. O., Fiadeiro, P. T., Costa, A. P., Amaral, M. E., and Belgacem, M. N. (2015). "Laser scanning for assessment of the fiber anisotropy and orientation in the surfaces and bulk of the paper," Nordic Pulp \& Paper Research Journal 30(2), 308-318. DOI: 10.3183/npprj-2015-30-02-p308-318

Milanez, A. F., and Rost, É. (2005). Tissue Paper - Revisão Tecnológica (Report No. P\&D 306-05), Suzano Papel E Celulose SA, Suzano-SP, Brazil. DOI: $10.13140 / 2.1 .1629 .4726$

Spina, R., and Cavalcante, B. (2018). "Characterizing materials and processes used on paper tissue converting lines," Materials Today Communications 17, 427-437. DOI: 10.1016/j.mtcomm.2018.10.006

Tutuş, A., Çiçekler, M., and Çali, A. (2016). "Tissue papers in Turkey and some physical and optical properties," Journal of Natural and Applied Sciences 20(1), 98-102.

Article submitted: November 12, 2019; Peer review completed: March 8, 2020; Revised version received and accepted: March 21, 2020; Published: April 7, 2020.

DOI: 10.15376/biores.15.2.3888-3898 